\title{
The Poisoning Severity Score: If It Did Not Exist, We Would Have To Invent It
}

\author{
Rose Cairns $^{1,2}$ - Nicholas A. Buckley ${ }^{1,2}$ \\ Received: 19 April 2017 / Accepted: 25 April 2017/Published online: 17 May 2017 \\ (C) American College of Medical Toxicology 2017
}

Keywords Poisoning severity score $\cdot$ Severity score .

Poisoning $\cdot$ Toxicology $\cdot$ Poisons centres

The Poisoning Severity Score (PSS), described in a review article by Schwarz and co-authors in this issue of JMT [1], is a tool developed by the European Association of Poisons Centres and Clinical Toxicologists (EAPCCT), the International Programme on Chemical Safety, and the European Commission in the 1990s [2]. It was developed to allow comparison between poisoning exposures, has been used in hundreds of studies, and cited over 450 times (Google Scholar cites for Ref. [2]). It has a wide range of applications; is particularly useful to compare outcomes between substances/classes, dose, and exposure types; and allows quantitative evaluation of poisoning morbidity. Additionally, it allows evaluation of risks from emerging poisonings. Importantly, if many sites/countries use the PSS, this allows aggregation and comparison of data. Thus, the PSS is useful for clinical and epidemiological studies, with examples shown in Table 1. It is a summary outcome measure based on the final outcome. It was not designed for prognostic studies. So when it is used this way, it obviously has to be modified to only include information generally

Electronic supplementary material The online version of this article (doi:10.1007/s13181-017-0614-8) contains supplementary material, which is available to authorized users.

Nicholas A. Buckley

Nicholas.buckley@sydney.edu.au

1 New South Wales Poisons Information Centre, The Children's Hospital at Westmead, Westmead, NSW 2145, Australia

2 Discipline of Pharmacology, School of Medical Sciences, Sydney Medical School, The University of Sydney, Camperdown, Australia collected prior to the timepoint of prognostication (otherwise it would be predicting itself).

\section{The Narcissism of Small Differences}

The PSS classifies poisoning severity as none (0), minor (1), moderate (2), severe (3), and fatal (4). The PSS is seldom used in North America. However, the annual report from the American Association of Poison Control Centers' (AAPCC) National Poison Data System (NPDS) demonstrates that American poison centres are using a very similar scoring system. Where cases are followed to a known outcome, exposures in the NPDS are coded as 0: no effect, 1: minor effect, 2: moderate effect, 3: major effect, and 4: death [28]. We struggled to find published information on how medical outcome severity is classed by NPDS poison control centre staff (however, brief descriptions are provided in Appendix A of the annual report). We obtained the NPDS Coding Users' Manual (Version 3.1) [29] and compared examples given to those in the PSS guidelines. We found that 10/10 examples in the NPDS guide as 'minor effect' would also be classed as 'minor' by the PSS. 12/18 NPDS examples for 'moderate effect' would be classed as 'moderate' by PSS; the remainder are unable to be classified due to insufficient information in the NPDS (e.g. NPDS 'acid-base disturbance' could be minor, moderate or severe on PSS depending on the deviation from normal). All 14 NPDS examples for 'Major effect' would be classed as 'Severe' by PSS. The NPDS and PSS systems appear very similar, with the main difference that the lack of detail in NPDS is likely to reduce inter-rater reliability. A third, new poisoning severity scoring system is currently under development, the 'ToxIC Severity Score' (TSS) [30]. Table 2 compares the PSS and NPDS systems and uses metabolic balance as an example, demonstrating the specific 
Table 1 Examples of types of studies where the PSS has been used

\begin{tabular}{lll}
\hline Study type & Examples & $\begin{array}{c}\text { Example } \\
\text { references }\end{array}$ \\
\hline Comparative toxicity & $\begin{array}{l}\text { Compare severity of different types of exposures e.g. } \\
\text { pharmaceuticals vs pesticides } \\
\text { Compare different agents within a class e.g. psychotropics, }\end{array}$ & {$[3]$} \\
& antihypertensives, household products, plants \\
& Selection of severe/fatal cases for further evaluation & {$[4-8]$} \\
& Effect of patient/case characteristics on outcome (e.g. age, gender, & {$[10,11]$} \\
Predictors of severity & exposure intent, time to hospitalisation) & {$[9]$} \\
& $\begin{array}{l}\text { Patterns of exposure predicting toxicity e.g. acute on chronic } \\
\text { lithium exposure }\end{array}$ & {$[12]$} \\
Analysis of one & Effect of dose on toxicity & {$[13-16]$} \\
agent/class & Document toxicity for a specific class/substance e.g. paediatric & {$[17,18]$} \\
pesticides, baclofen & {$[19-23]$} \\
Emerging poisoning & New psychoactive substances (NPS) & {$[24]$} \\
hazards & Laundry pods & {$[25]$} \\
& Body building/weight loss supplements e.g. 2,4-dinitrophenol \\
& (DNP) & {$[16,26]$} \\
Evaluation of & Evaluate effect of decontamination & {$[27]$} \\
interventions & Trends in severity over time e.g. paediatric cannabis intoxication & {$[8]$} \\
Documentation of trends & Multi-centre/multi-country studies, aggregating summary data & \\
Aggregation of data from & using the PSS & \\
several sources & & \\
\hline
\end{tabular}

parameters in the PSS compared to more general terms in the NPDS manual (see Supplementary Table 1 for a full comparison of components of the PSS and NPDS scoring systems, in addition to proposed elements in the TSS).

\section{Reinventing the Wheel}

No clinical severity score can be perfect. In this issue of JMT, Schwarz and colleagues discuss limitations of the PSS [1]. The PSS and NPDS scores are easy to criticise, but much harder to improve on. For clinical research and audit purposes, we need a standardised way to broadly classify the severity of poisonings that does not involve re-examining individual case records to judge what happened. Poisons centres across Europe and elsewhere apply the PSS on a daily basis for every exposure call, indicating ease of use, and a PSS-like system is being used daily in the USA (a similar system appears to be in place in Canada [31]). The PSS and NPDS scoring systems are very similar; indeed, the NPDS stratification was the starting point from which the PSS was formulated. The PSS is more detailed as a result of testing and revision processes done to improve inter-rater agreement [2]. The AAPCC annual report is the most widely cited paper in the field of medical toxicology; it uses the 5-point NPDS score (on which the PSS was based) to report on the relative severity of all drugs, poisoning by age group, by intent, by duration, and by year [28]. Unfortunately, it does not reference any papers on how it was developed or if it was validated.
Thus, we currently have two systems that largely serve the same purpose. Criticisms that apply to the PSS (e.g. subjective variables, using a single tool to describe the breadth of poisonings [1]) apply to an even greater extent to the NPDS system. The proposed TSS items are notable for the fact that they do not include many components that would allow the PSS or NPDS score to be calculated and compared to their new scoring system on the same patients. This makes this process useless for supporting further modifications or validations of either existing score. This could actually be a backwards step; the most likely result three poisoning scores with factions supporting each.

\section{Divided by a Common Language?}

The greater problem, not highlighted by this review, is that we already have two widely used poisoning severity scores. All studies using a 5-point poisoning severity scale would benefit from a common scoring system. It would open up a range of new collaborative opportunities across the world. For example, we could compare the severity of various sorts of poisoning between countries based on how they regulate chemicals and pesticides, or their consumer protection laws. A PSS remains the best (i.e. least worst) way to compare poisoning severity across different agents, patient groups, geographic locations, and countries. If there are obvious ways to improve it, then let us all work together to do that. The PSS exists, we do not have to invent it, but together we could reinvent it. 
Table 2 Comparison of the PSS and NPDS severity scoring system

\begin{tabular}{|c|c|c|}
\hline & PSS [2] & NPDS [29] \\
\hline \multicolumn{3}{|l|}{ Description of severity grades } \\
\hline 0 & $\begin{array}{l}\text { None: no symptoms or signs related to } \\
\text { poisoning }\end{array}$ & $\begin{array}{l}\text { No effect: The patient developed no symptoms as a result of } \\
\text { the exposure }\end{array}$ \\
\hline 1 & $\begin{array}{l}\text { Minor: mild, transient, and spontaneously } \\
\text { resolving symptoms }\end{array}$ & $\begin{array}{l}\text { Minor effect: Symptoms that were minimally bothersome and } \\
\text { resolved rapidly, with no residual disability or disfigurement }\end{array}$ \\
\hline 2 & $\begin{array}{l}\text { Moderate: pronounced or prolonged } \\
\text { symptoms }\end{array}$ & $\begin{array}{l}\text { Moderate effect: Symptoms that were more pronounced, more } \\
\text { prolonged, or more of a systemic nature than minor } \\
\text { symptoms. Symptoms were non-life threatening, with no } \\
\text { residual disability or disfigurement }\end{array}$ \\
\hline 3 & $\begin{array}{l}\text { Severe: severe or life-threatening } \\
\text { symptoms }\end{array}$ & $\begin{array}{l}\text { Major effect: Life-threatening symptoms or symptoms that } \\
\text { resulted in significant residual disability or disfigurement }\end{array}$ \\
\hline 4 & Fatal: death & Death \\
\hline $\begin{array}{l}\text { Example: Metabolic balance, from [2] and } \\
\text { the examples given in the NPDS coding } \\
\text { users' manual, [29] }\end{array}$ & 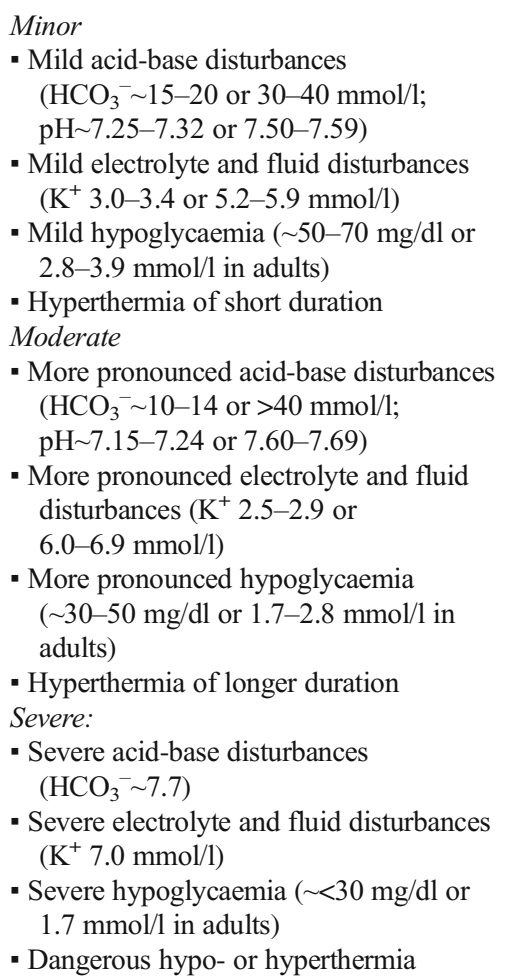 & $\begin{array}{l}\text { Moderate: } \\
\text { - Acid-base disturbance } \\
\text { - High fever } \\
\text { - Methanol ingestion manifesting only anion gap metabolic } \\
\quad \text { acidosis } \\
\text { - Aspirin overdose with acidosis, anion gap, and no alteration } \\
\text { in mental status } \\
\text { - Hypoglycaemia with confusion }\end{array}$ \\
\hline
\end{tabular}

\section{Compliance with Ethical Standards}

Conflicts of Interest The authors declare that they have no conflicts of interest.

Sources of Funding None to declare.

\section{References}

1. Schwarz ES, Kopec KT, Wiegand TJ, Wax PM, Brent J. Should we be using the poisoning severity score? J Med Toxicol. 2017; doi:10. 1007/s13181-017-0609-5.

2. Persson HE, Sjöberg GK, Haines JA, de Pronczuk Garbino J. Poisoning severity score. Grading of acute poisoning. J Toxicol Clin Toxicol. 1998;36:205-13. doi:10.3109/15563659809028940.
3. Balme K, Roberts JC, Glasstone M, Curling L, Mann MD. The changing trends of childhood poisoning at a tertiarychildren's hospital in South Africa. South African Med J. 2012;102:142-6.

4. Williams H, Moyns E, Bateman DN, Thomas SHL, Thompson JP, Vale JA, et al. Hazard of household cleaning products: a study undertaken by the UK National Poisons Information Service. Clin Toxicol. 2012;50:770-5. doi:10.3109/15563650.2012.709936.

5. Yilmaz Z, Ceschi A, Rauber-Lüthy C, Sauer O, Stedtler U, Prasa D, et al. Escitalopram causes fewer seizures in human overdose than citalopram. Clin Toxicol. 2010;48:207-12. doi:10.3109/ 15563650903585937.

6. Fuchs J, Rauber-Lüthy C, Kupferschmidt H, Kupper J, KullakUblick G-A, Ceschi A. Acute plant poisoning: analysis of clinical features and circumstances of exposure. Clin Toxicol. 2011;49: 671-80. doi:10.3109/15563650.2011.597034.

7. Hetterich N, Lauterbach E, Stürer A, Weilemann LS, Lauterbach M. Toxicity of antihypertensives in unintentional poisoning of 
young children. J Emerg Med. 2014;47:155-62. doi:10.1016/j. jemermed.2014.02.006.

8. Meli M, Rauber-Lüthy C, Hoffmann-Walbeck P, Reinecke HJ, Prasa D, Stedtler U, et al. Atypical antipsychotic poisoning in young children: a multicentre analysis of poisons centres data. Eur J Pediatr. 2014;173:743-50. doi:10.1007/s00431-013-2241-y.

9. Anderson M, Hawkins L, Eddleston M. Severe and fatal pharmaceutical poisoning in young children in the UK. Arch Dis Child. 2016;50:1-4. doi:10.1136/archdischild-2015-309921.

10. Giannini L, Vannacci A, Missanelli A, Mastroianni R, Mannaioni $\mathrm{PF}$, Moroni F, et al. Amatoxin poisoning: a 15-year retrospective analysis and follow-up evaluation of 105 patients. Clin Toxicol. 2007;45:539-42. doi:10.1080/15563650701365834.

11. Bentur Y, Raikhlin-eisenkraft B, Lavee M. Toxicological features of deliberate self-poisonings. Hum Exp Toxicol. 2004;23:331-7. doi: 10.1191/0960327104ht454oa.

12. Waring WS, Laing WJ, Good AM, Bateman DN. Pattern of lithium exposure predicts poisoning severity: evaluation of referrals to a regional poisons unit. QJM. 2007;100:271-6. doi:10.1093/qjmed/ hem017.

13. Radovanovic D, Meier PJ, Guirguis M, Lorent JP, Kupferschmidt H. Dose-dependent toxicity of diphenhydramine overdose. Hum Exp Toxicol. 2000;19:489-95. doi:10.1191/096032700671040438.

14. Langford NJ, Good AM, Laing WJ, Bateman DN. Quinine intoxications reported to the Scottish Poisons Information Bureau 19972002: a continuing problem. Br J Clin Pharmacol. 2003;56:576-8. doi:10.1046/j.1365-2125.2003.01921.x.

15. Krämer I, Rauber-Lüthy C, Kupferschmidt H, Krähenbühl S, Ceschi A. Minimal dose for severe poisoning and influencing factors in acute human clozapine intoxication: a 13-year retrospective study. Clin Neuropharmacol. 2010;33:230-4. doi:10.1097/WNF. 0b013e3181f0ec55.

16. Prasa D, Hoffmann-Walbeck P, Barth S, Stedtler U, Ceschi A, Färber E, et al. Angiotensin II antagonists - an assessment of their acute toxicity. Clin Toxicol. 2013;51:429-34. doi:10.3109/ 15563650.2013.800875.

17. Adams RD, Lupton D, Good AM, Bateman DN. UK childhood exposures to pesticides 2004-2007: a TOXBASE toxicovigilance study. Arch Dis Child. 2009;94:417-20. doi:10.1136/adc.2008. 144972.

18. Kiel LB, Hoegberg LCG, Jansen T, Petersen JA, Dalhoff KP. A nationwide register-based survey of baclofen toxicity. Basic Clin Pharmacol Toxicol. 2015;116:452-6. doi:10.1111/bcpt.12344.

19. Helander A, Beck O, Backberg M. Intoxications by the dissociative new psychoactive substances diphenidine and methoxphenidine. Clin Toxicol. 2015;53:446-53. doi:10.3109/15563650.2015. 1033630
20. Beck O, Franzen L, Backberg M, Signell P, Helander A. Intoxications involving MDPV in Sweden during 2010-2014: results from the STRIDA project. Clin Toxicol. 2015;53:865-73. doi: 10.3109/15563650.2015.1089576.

21. Hermanns-Clausen M, Kneisel S, Szabo B, Auwärter V. Acute toxicity due to the confirmed consumption of synthetic cannabinoids: clinical and laboratory findings. Addiction. 2013;108:534 44. doi:10.1111/j.1360-0443.2012.04078.x.

22. Helander A, Bäckberg M, Hultén P, Al-Saffar Y, Beck O. Detection of new psychoactive substance use among emergency room patients: results from the Swedish STRIDA project. Forensic Sci Int. 2014;243:23-9. doi:10.1016/j.forsciint.2014.02.022.

23. Waugh J, Najafi J, Hawkins L, Hill SL, Eddleston M, Vale JA, et al. Epidemiology and clinical features of toxicity following recreational use of synthetic cannabinoid receptor agonists: a report from the United Kingdom National Poisons Information Service. Clin Toxicol. 2016;54:512-8. doi:10. 3109/15563650.2016.1171329.

24. Williams H, Jones S, Wood K, Scott RAH, Eddleston M, Thomas SHL, et al. Reported toxicity in 1486 liquid detergent capsule exposures to the UK National Poisons Information Service 20092012, including their ophthalmic and CNS effects. Clin Toxicol. 2014;52:136-40. doi:10.3109/15563650.2013.855315.

25. Kamour A, George N, Gwynnette D, Cooper G, Lupton D, Eddleston $\mathrm{M}$, et al. Increasing frequency of severe clinical toxicity after use of 2,4-dinitrophenol in the UK: a report from the National Poisons Information Service. Emerg Med J. 2014:1-4. doi:10. 1136/emermed-2013-203335.

26. Bretaudeau Deguigne M, Hamel JF, Boels D, Harry P. Lithium poisoning: the value of early digestive tract decontamination. Clin Toxicol. 2013;51:243-8. doi:10.3109/15563650.2013.782409.

27. Claudet I, Le Breton M, Bréhin C, Franchitto N. A 10-year review of cannabis exposure in children under 3-years of age: do we need a more global approach? Eur J Pediatr. 2017;176:553-6. doi:10. 1007/s00431-017-2872-5.

28. Mowry A, Spyker D, Brooks D, McMillan N, Schauben J. 2014 annual report of the American Association of Poison Control Centers' National Poison Data System (NPDS). Clin Toxicol. 2014;53:962-1146. doi:10.1080/15563650701754763.

29. American Association of Poison Control Centers. National Poison Data System (NPDS): NPDS Coding Users' Manual. Version 3. 2014.

30. American College of Medical Toxicology. ToxIC Severity Score 2017. http://www.acmt.net/cgi/page.cgi/Severity_Score_Registry. html.

31. Ontario Poison Centre. Ontario Poison Centre Annual Report 2009. 